\title{
Epidemiological characterization and risk factors associated with leptospirosis and brucellosis in small ruminants sold at animal fair in the Sertão Region of Pernambuco State, a semiarid Region of Northeastern Brazil
}

\author{
Caracterização epidemiológica e fatores de risco associados à \\ leptospirose e brucelose em pequenos ruminantes comercializados \\ em feira de animais no Sertão de Pernambuco, semiárido do \\ Nordeste do Brasil
}

José Romero Alexandre Alves ; Geilson Manoel de Souza Lima²; José Dêvede da Silva ${ }^{3}$; Diego Figueiredo da Costa ${ }^{1} ;$ Fabrine Alexandre dos Santos $^{1}$; Severino Silvano dos Santos Higino ${ }^{4}$; Sérgio Santos de Azevedo ${ }^{4}$; Clebert José Alves ${ }^{4 *}$

\begin{abstract}
The transit of infected animals may be a route for the introduction and dispersal of diseases, which necessitates protocols for the controlled entry of infected animals into herds. The objective of this study was to determine the prevalence of anti-Leptospira and anti-Brucella ovis antibodies in small ruminants sold at an animal fair in the Sertão region of the Pernambuco State, Northeastern Brazil, and to identify the possible risk factors associated with seropositivity. Serum samples were collected from 233 goats and 119 sheep, belonging to twelve different owners from November 2014 to June 2015. Diagnosis of Leptospira spp. infection was established using the microscopic agglutination test (MAT); for B. ovis infection, the agar gel immuno-diffusion (AGID) test was conducted. A total of 16/233 $(6.87 \%$; $95 \%$ $\mathrm{CI}=4.27 \%-10.83 \%)$ goats and $16 / 119(13.45 \% ; 95 \% \mathrm{CI}=8.67 \%-21.24 \%)$ sheep were identified as seropositive for Leptospira spp. The most frequent serotype was Icterohaemorrhagiae. In goats, intensive management system (odds ratio $=15.8 ; \mathrm{p}<0.001$ ) and consorted rearing of equines and goats (odds ratio $=7.3 ; \mathrm{p}=0.005$ ) were identified as risk factors. There were no risk factors identified for sheep. Seven $(5.88 \% ; 95 \%$ CI $=2.88 \%-11.65 \%)$ sheep were seropositive for $B$. ovis, and the intensive management system was identified as the risk factor (odds ratio $=11.5 ; \mathrm{p}=0.005$ ). This suggests that Leptospira spp. and B. ovis infections occur in small ruminants commercialized in the Sertão region of the Pernambuco State. Thus, improvements to the sanitary conditions of the facilities and the control of synanthropic rodents are recommended.
\end{abstract}

Key words: Serology. Leptospirosis. Ovine brucellosis. Risk factors. Agglomerations.

\footnotetext{
${ }^{1}$ Discentes de Doutorado, Programa de Pós-Graduação em Medicina Veterinária, Universidade Federal de Campina Grande, UFCG, Patos, PB, Brasil.E-mail: j.romeroalves@bol.com.br; diegoveter@hotmail.com; fabrinevet@yahoo.com.br

2 Discente, Curso de Graduação em Medicina Veterinária, UFCG, Patos, PB, Brasil. E-mail: geilsonmsl@hotmail.com

${ }_{3}$ Discente de Mestrado, Programa de Pós-Graduação em Medicina Veterinária, Universidade Federal de Campina Grande, UFCG, Patos, PB, Brasil. E-mail: dvd.12@hotmail.com

4 Profs., Programa de Pós-Graduação em Medicina Veterinária, UFCG, Patos, PB, Brasil. E-mail: sergio@vps.fmvz.usp.br; clebertja@uol.com.br

* Author for correspondence
} 


\section{Resumo}

O trânsito de animais infectados pode ser uma forma de introdução e dispersão de enfermidades, de maneira que o bloqueio da entrada de animais infectados nos rebanhos é uma importante ferramenta de controle. O objetivo desse estudo foi determinar a frequência de anticorpos anti-Leptospira spp. e antiBrucella ovis em pequenos ruminantes comercializados em feira de animais no Sertão de Pernambuco, Nordeste do Brasil, e identificar os possíveis fatores de risco associados às soropositividades. Foram coletadas amostras de soro de 233 caprinos e 119 ovinos, pertencentes a doze proprietários diferentes, no período de novembro de 2014 a junho de 2015. O diagnóstico da infecção por Leptospira spp. foi realizado pela técnica de soroaglutinação microscópica (SAM), e para B. ovis o teste de imunodifusão em gel de ágar (IDGA) foi aplicado. Foram identificados 16 (6,87\%; IC 95\% = 4,27\% - 10,83\%) caprinos e $16(13,45 \%$; IC 95\% $=8,67 \%$ - 21,24\%) ovinos soropositivos para Leptospira spp. O sorotipo mais frequente foi o Icterohaemorrhagiae. Em caprinos, a criação de forma intensiva (odds ratio $=15,8 ; \mathrm{p}<0,001$ ) e criar equinos consorciados com caprinos (odds ratio $=7,3 ; \mathrm{p}=0,005$ ) foram identificados como fatores de risco. Não foi identificado fator de risco associado à infecção em ovinos. Sete $(5,88 \%$; IC $95 \%=2,88 \%$ - 11,65\%) ovinos foram soropositivos para B. ovis, e a criação intensiva foi considerada fator de risco (odds ratio $=11,5 ; \mathrm{p}=0,005$ ). Sugere-se que as infecções por Leptospira spp. e B. ovis ocorrem pequenos ruminantes comercializados no Sertão do Estado de Pernambuco, bem como recomenda-se melhorias nas condições higiênico-sanitárias das instalações e controle de roedores sinantrópicos.

Palavras-chave: Serologia. Leptospirose. Brucelose ovina. Fatores de risco. Aglomerações.

\section{Introduction}

Among the bacterial diseases that cause reproductive losses in the rearing of goats and sheep, we investigated the incidence of leptospirosis and brucellosis. Leptospirosis is a zoonosis that has been distributed worldwide; it is caused by bacteria of the Leptospira genus (ADLER; DE LA PEÑA MOCTEZUMA, 2010), and is responsible for the incidence of abortions, the birth of weak and premature offspring, and the drop in milk production (ELLIS, 2015). The incidence of ovine brucellosis is caused by Brucella ovis; it is an infectious disease that occurs primarily in countries where sheep farming is practiced. The disease has been responsible for the reported reproductive losses that have occurred as a result of the reduced fertility of the herds (OIE, 2015). This disease has been addressed by the National Goat and Sheep Health Program (PNSCO) of the Ministry of Farming, Livestock and Food Supply (MAPA), which establishes the control of animal transit, registration and the inspection of agglomerations as infection control measures.

Serological studies show that infection by Leptospira spp. in small ruminants is widely distributed in Brazil. In goats, results vary from 1.5\% in Ceará State (FÁVERO et al., 2002) to $35.47 \%$ in the Santa Catarina State (TOPAZIO et al., 2015). In sheep, the rate varies from $0.7 \%$ in São Paulo State (FÁVERO et al., 2002) to $47.4 \%$ in Rio de Janeiro State (MARTINS et al., 2012). Infection by $B$. ovis has also been diagnosed in several Brazilian states with variations between $0.72 \%$ in Bahia State (SOUZA et al., 2012) and 34\% in Rio Grande do Norte State (SILVA et al., 2003).

The diagnosis of these diseases in herds that participate in agglomerations, such as live animal fairs, is of utmost importance. These events are common in the Northeastern regions, where goats and sheep are sold either mainly by the farmers themselves or, in most cases, by intermediate traders, who purchase the animals from the properties of the region and externally resell them, such as at fairs (NOGUEIRA FILHO et al., 2010). The goal of this study is, therefore, to determine the frequency of seropositivity for Leptospira spp. and $B$. ovis in small ruminants sold at animal fairs in the Sertão [wilderness] region of Pernambuco State, Northeast of Brazil, as well as to identify the risk factors associated with seropositivity. 


\section{Material and Methods}

The study was conducted at the live animal fair in the Tabira municipality (latitude $07^{\circ} 35^{\prime} 31^{\prime \prime} \mathrm{S}$ and longitude $\left.37^{\circ} 32^{\prime} 24^{\prime \prime} \mathrm{O}\right)$, located in the Development Region of Pajeú Sertão, Pernambuco State. The fair is held weekly, starting on Tuesdays and extending to Wednesday afternoons, and receives animals from Pernambuco and other Northeastern states. The primary animals sold are cattle and small ruminants, and, due to the quantity of sales, it is considered to be an important trade center in the region.

The population studied was composed of fleeced adult goats and sheep ( $>6$ months of age), of both sexes, and without a defined racial standard. The following parameters were considered for the calculation of the minimum number of animals to be sampled: (a) expected prevalence of each disease; (b) an absolute error of 5\%; and (c) a confidence level of $95 \%$, according to the formula for simple random samples (THRUSFIELD, 2007). For the incidence of leptospirosis infection in goats, a prevalence of $8.7 \%$ was considered (HIGINO et al., 2013), and in sheep, 5.41\% (ALVES et al., 2012); for ovine brucellosis, a prevalence of $5.02 \%$ was considered (SANTOS et al., 2012). For sheep, the final sample "n" was that resulting from the highest expected prevalence (leptospirosis) for sample maximization. According to these parameters, the minimum sample "n" was 122 goats and 79 sheep. However, 233 goats and 119 sheep were used, totaling 352 samples.

The owners who participated in the research were selected using convenience sampling (THRUSFIELD, 2007). The number of samples per collection was based on the total number of animals that entered the fair. This data was obtained from the report on animal admission to the site, through Animal Transit Forms (GTAs) presented by the owners. The data was granted by the Pernambuco State Farming \& Livestock Defense and Inspection Agency (ADAGRO). A total of 12 owners agreed to take part in the research, providing the respective
Informed Consent Forms, and the animals were selected at random from those present in the facilities where the herds were sold.

The collections were made in the period of November 2014 to June 2015 in order to consider both the rainy and dry seasonal changes of the region. Out of the 233 goats used, 206 originated from Pernambuco State and 27 from Bahia State. With regard to the sheep, 93 came from Pernambuco State and 26 from Bahia State, totaling 119 animals. Each owner answered the epidemiological questionnaire through an interview during the collections, discussing the variables related to the general aspect of the property, such as herd size, facilities, animal species, types of exploitation and rearing, production commercialization route, food management, zootechnical control, and the health management and the occurrence of illnesses and/ or symptoms of diseases including reproductive disorders, joint problems, symptoms of caseous lymphadenitis, weight loss, pneumonia, diarrhea, anemia and nervous disorders.

The presence of anti-Leptospira spp. antibodies was determined via the microscopic agglutination test (MAT) (OIE, 2014). The antigens that were used included a collection of strains of Leptospira biflexa Andamana and Patoc serotypes; Leptospira interrogans Australis, Copenhageni, Bataviae, Bratislava, Canicola, Grippotyphosa, Hardjoprajitno, Pomona, Pyrogenes, Icterohaemorrhagiae, Hebdomadis, Wolffi and Butembo serotypes; Leptospira borgpetersenii Autumnalis, Castellonis, Hardjo-bovis, Javanica and Tarassovi serotypes; Leptospira santarosai Guaricura and Shermani serotypes; Leptospira kirschneri Cynopteri serotype; and Leptospira noguchii Panama serotype, granted by the Veterinary Bacteriology Lab of the Federal Fluminense University (UFF) and from the Pasteur Institute, in France. The serum samples were screened in dilutions of 1:100, and those that presented $50 \%$ or more agglutination were titrated by examining a series of geometrical dilutions with a ratio of two. The serum titer was a reciprocal of 
the highest dilution that presented a positive result. The antigens were examined under the dark field microscope, before the tests, in order to verify the mobility and presence of self-agglutination or contaminants.

The agar gel immuno-diffusion (AGID) technique was used to diagnose infection by $B$. ovis using kits produced by the Parana Technology Institute (TECPAR), carefully following the manufacturer's instructions and using proteins and lipopolysaccharides from the Reo 198 sample as antigens (OIE, 2015). To check for the occurrence of smooth anti-Brucella antibodies, the Buffered Acidified Plate Antigen (BAPA) test was used with the antigens produced by TECPAR, following the manufacturer's recommendations.

The results of the diagnostic tests and information from the epidemiological questionnaire were stored in a database using Microsoft Excel ${ }^{\circledR}$. Univariate and multivariate analyses were conducted to identify the risk factors. In the univariate analysis, the independent variables were subjected to association analysis with the dependent variable (serology result), and those with a value of $\mathrm{p} \leq 0.2$, using the chi-square test (ZAR, 1999), were selected for the multivariate analysis by multiple logistic regression (HOSMER; LEMESHOW, 2000). The significance level adopted in the multiple analysis was $5 \%$, and all analyses were conducted with the SPSS 20.0 for Windows software.

The project was evaluated and approved by the Research Ethics Committee (REC) of the Rural Health and Technology Center (CSTR/UFCG), and filed under number 184/2014.

\section{Results}

Out of the 233 goats evaluated for leptospirosis, $16(6.87 \%$; CI $95 \%=4.27 \%-10.83 \%)$ were seropositive; similarly, 16 sheep $(13.45 \%$; CI 95\% = $8.67 \%-21.24 \%$ ) were also seropositive. The most frequent serotype among the goats was the incidence of Icterohaemorrhagiae (37.5\%), followed by Grippotyphosa \& Tarassovi (18.75\%), Autumnalis (12.5\%), and Canicola and Copenhageni (6.25\%) (Table 1).Among the sheep, the Icterohaemorrhagiae serotype was the most frequent $(62.5 \%)$, followed by Canicola (12.5\%), Bratislava, Grippotyphosa, and Wolffi and Hadjoprajitno (6.25\%) (Table 2). Out of the 119 sheep serum samples that were tested for the incidence of $B$. ovis infection, seven animals $(5.88 \%$; CI $95 \%=2.88 \%-11.65 \%)$ were seropositive. A negative result was evident for all animals tested for the smooth Brucella strain via the BAPA technique.

Table 1. The most prevalent serotypes of Leptospira spp., and their respective titrations recorded in goats sold at an animal fair between November 2014 and June 2015 in the Tabira Municipality, Pernambuco State, in the northeastern semiarid region.

\begin{tabular}{llllll}
\hline \multirow{2}{*}{ Serotypes } & Titers & & & & \multirow{2}{*}{ Total (\%) } \\
\cline { 2 - 5 } & 100 & 200 & 400 & 800 & $6(37.50)$ \\
Icterohaemorrhagiae & 1 & 2 & 3 & - & $3(18.75)$ \\
Grippotyphosa & 1 & - & 1 & 1 & $3(18.75)$ \\
Tarassovi & 1 & 2 & - & - & $2(12.50)$ \\
Autumnalis & 2 & - & - & - & $1(6.25)$ \\
Canicola & 1 & - & - & - & $1(6.25)$ \\
Copenhageni & - & - & 1 & - & $16(100)$ \\
\hline Total $(\%)$ & $6(37.50)$ & $4(25.00)$ & $5(31.25)$ & $1(6.25)$ & \\
\hline
\end{tabular}


Table 3 and 4 show the variables most associated $(\mathrm{p} \leq 0.2)$ with positivity for the incidence of leptospirosis infection in goats, and brucellosis in sheep, respectively, from the univariate analysis. In the final logistic regression model (Table 5), the intensive management system (odds ratio $=15.8$; $\mathrm{p}<0.001)$ and the practice of consort rearing for horses and goats (odds ratio $=7.3 ; p=0.005$ ) were identified as risk factors for leptospirosis in goats; the intensive management system (odds ratio = $11.5 ; \mathrm{p}=0.005$ ) was identified as a risk factor for brucellosis in sheep. There were no risk factors identified for leptospirosis in sheep.

Table 2. The most prevalent serotypes of Leptospira spp. and their respective titrations recorded in sheep sold at an animal fair between November 2014 and June 2015 in the Tabira Municipality, Pernambuco State, in the northeastern semiarid region.

\begin{tabular}{lllll}
\hline \multirow{2}{*}{ Serotypes } & Titers & & & \multirow{2}{*}{ Total (\%) } \\
\cline { 2 - 5 } & 100 & 200 & 400 & $10(62.50)$ \\
Icterohaemorrhagiae & 4 & 2 & 4 & $2(12.50)$ \\
Canicola & 2 & - & - & $1(6.25)$ \\
Bratislava & 1 & - & - & $1(6.25)$ \\
Grippotyphosa & 1 & - & - & $1(6.25)$ \\
Wollfi & 1 & - & - & $1(6.25)$ \\
Hadjoprajitno & 1 & - & - & $16(100)$ \\
\hline Total (\%) & $10(62.50)$ & $2(12.50)$ & $4(25.00)$ & \\
\hline
\end{tabular}

Table 3. The results of the univariate analysis showing the variables considered for correlativity $(\mathrm{p}<0.2)$ with seropositivity for Leptospira spp. in goats sold at an animal fair in the Tabira Municipality, Pernambuco State, between November 2014 and June 2015.

\begin{tabular}{lllll}
\hline Variable & Category & Total animals & $\begin{array}{c}\text { Positive } \\
(\%)\end{array}$ & $p$ \\
\hline Activity & Rural farmer & 147 & $8(5.4)$ & \\
& Salaried/retired worker & 61 & $2(3.3)$ & \\
& Trader & 25 & $6(24.0)$ & 0.001 \\
Profile & Owner/tenant & 206 & $10(4.9)$ & \\
& Others & 27 & $6(22.2)$ & 0.005 \\
Breeds cattle & No & & & \\
& Yes & 67 & $2(3.0)$ & \\
Breeds pigs & No & 166 & $14(8.4)$ & 0.11 \\
& Yes & 119 & $2(1.7)$ & \\
Breeds horses & No & 114 & $14(12.3)$ & 0.001 \\
& Yes & 178 & $9(5.1)$ & \\
Management system & Intensive & 55 & $7(12.7)$ & 0.054
\end{tabular}


continuation

\begin{tabular}{|c|c|c|c|c|}
\hline \multirow[t]{2}{*}{ Type of production } & Meat & 50 & $0(0.0)$ & \\
\hline & Dairy/mixed & 183 & $16(8.7)$ & 0.018 \\
\hline \multirow[t]{3}{*}{ Herd size } & Up to 49 animals & 30 & $1(3.3)$ & \\
\hline & 50 to 100 animals & 170 & $9(5.3)$ & \\
\hline & $>100$ animals & 33 & $6(18.2)$ & 0.02 \\
\hline \multirow[t]{2}{*}{ Uses caatinga [savanna vegetation] as source of food } & No & 27 & $6(22.2)$ & \\
\hline & Yes & 206 & $10(4.9)$ & 0.005 \\
\hline \multirow[t]{2}{*}{ Disinfection of the navel of the newborns } & No & 166 & $14(8.4)$ & \\
\hline & Yes & 67 & $2(3.0)$ & 0.11 \\
\hline
\end{tabular}

Table 4. The results of the univariate analysis showing the variables considered for correlativity $(\mathrm{p}<0.2)$ with seropositivity for Brucella ovis in sheep sold at an animal fair in the Tabira Municipality, Pernambuco State, in the northeastern semiarid region, between November 2014 and June 2015.

\begin{tabular}{|c|c|c|c|c|}
\hline Variable & Category & Total animals & Positive (\%) & $\mathrm{p}$ \\
\hline \multirow[t]{2}{*}{ Management system } & Intensive & 25 & $5(20.0)$ & \\
\hline & Semi-intensive/extensive & 94 & $2(2.1)$ & 0.004 \\
\hline \multirow[t]{2}{*}{ Type of production } & Meat & 25 & $5(20.0)$ & \\
\hline & Dairy/mixed & 94 & $2(2.1)$ & 0.004 \\
\hline \multirow[t]{2}{*}{ Takes animals to other events } & No & 55 & $1(1.8)$ & \\
\hline & Yes & 64 & $6(9.40)$ & 0.081 \\
\hline \multirow[t]{3}{*}{ Flock of sheep } & Up to 49 animals & 29 & $0(0.0 \%)$ & \\
\hline & 50 to 100 animals & 13 & $0(0.0 \%)$ & \\
\hline & $>100$ animals & 77 & $7(9.1 \%)$ & 0.132 \\
\hline \multirow[t]{2}{*}{ Receives technical assistance } & No & 45 & $5(11.1)$ & \\
\hline & Yes & 74 & $2(2.7)$ & 0.059 \\
\hline \multirow{2}{*}{ Controlled entry and exit of animals } & No & 80 & $7(8.8 \%)$ & \\
\hline & Yes & 39 & $0(0.0 \%)$ & 0.057 \\
\hline \multirow[t]{2}{*}{ Vaccinates the flock } & No & 52 & $6(11.5)$ & \\
\hline & Yes & 67 & $1(1.5)$ & 0.021 \\
\hline \multirow[t]{2}{*}{ Deworms the flock } & No & 25 & $5(20.0)$ & \\
\hline & Yes & 94 & $2(2.1)$ & 0.004 \\
\hline \multirow[t]{2}{*}{ Deworming frequency } & Annual & 32 & $1(3.1)$ & \\
\hline & Biannual or less & 62 & $1(1.6)$ & 0.003 \\
\hline
\end{tabular}


continuation

\begin{tabular}{lllll} 
Disinfection of the navel of the newborns & No & 66 & $6(9.1)$ & \\
& Yes & 53 & $1(1.9)$ & 0.097 \\
Occurrence of joint problems & No & 90 & $2(2.2)$ & \\
& Yes & 29 & $5(17.2)$ & 0.009 \\
Occurrence of abortion & No & & $2(2.3)$ & \\
& Yes & 86 & $5(15.2)$ & 0.017 \\
Request of veterinary care & No & 33 & $5(13.9)$ & \\
& Yes & 36 & $2(2.4)$ & 0.014 \\
\hline
\end{tabular}

Table 5. The risk factors for the incidence of Leptospira spp. infection in goats and B. ovis in sheep sold at an animal fair in the Tabira Municipality, Pernambuco State, in the northeastern semiarid region, between November 2014 and June 2015.

\begin{tabular}{llll}
\hline Risk factor & Odds ratio (OR) & CI 95\% & p \\
\hline Leptospirose (goats) & & & \\
Intensive management system & 15.8 & $3.6-68.4$ & $<0.001$ \\
Rearing horses & 7.3 & $1.8-29.3$ & 0.005 \\
& & & \\
B. ovis (sheep) & 11.5 & $2.1-63.6$ & 0.005 \\
Intensive management system & & & \\
\hline
\end{tabular}

\section{Discussion}

The frequency of goats seropositive for leptospirosis in this study were consistent with the seropositive rate of $8.7 \%$ previously reported for dairy goats originating from the northeastern semiarid regions by Higino et al. (2013). Seropositivity was also more prevalent among sheep in the semiarid regions of the Paraiba State, compared to the previously reported rates of $7.5 \%$ and $5.4 \%$, respectively, from the studies of Higino et al. (2010) and Alves et al. (2012). Nonetheless, Costa et al. (2016) reported that $11.2 \%$ of the sheep in the Paraiba State were seropositive.

The studied herds comprised mostly of animals without a defined racial standard, which possibly lowered the frequency of seropositive animals reported in this study. Nonetheless, this can be justified by the rusticity of the animals, combined with the region's environmental conditions. Some researchers observed that purebred animals showed greater susceptibility to the disease compared to crossbreeds (SANTOS et al., 2012; SILVA et al., 2012). Additionally, according to Lilenbaum et al. (2007), it was shown that animals reared from herds originating from the tropical climates were likelier to be seropositive, and that this was an observation consistent with previous reports indicating a higher prevalence of the disease among goats sampled from the tropical regions of Brazil: $25.9 \%$ in Rio de Janeiro (MARTINS et al., 2012) and 31.3\% in Minas Gerais (SANTOS et al., 2012). In comparison, the results commonly reported in the Northeastern regions were the following: $0.7 \%$ in Ceará (FÁVERO et al., 2002) and $14.5 \%$ in Rio Grande do Norte (ARAÚJO NETO et al., 2010). This difference in the prevalence of seropositive animals between the two regions was also similarly observed in studies conducted with sheep, in which the northeastern semiarid regions varied from $3.5 \%$ in Rio Grande do Norte (AZEVEDO et al., 2004a) to $7.5 \%$ in Paraiba 
(HIGINO et al., 2010). The majority of studies have also reported higher frequencies of seropositive herds from other regions of the country: $34.3 \%$ in Rio Grande do Sul (HERRMANN et al., 2004); $33.3 \%$ in Rondônia (AGUIAR et al., 2010); 22\% in Minas Gerais (SALABERRY et al., 2011); 47.4\% in Rio de Janeiro (MARTINS et al., 2012); and 22.8\% in São Paulo (RIZZO et al., 2014). Nonetheless, despite the low incidence of the disease, the carrier status of the animal should be noted as this may be an important mechanism for disease maintenance in herds, even if the bacterial contaminants are eliminated from the environment.

The most frequent serotype reported in this study was the incidence of Icterohaemorrhagiae infection for both goats and sheep. Higher rates of this serotype were also similarly reported among the sheep and goats from the Espírito Santo State (CORTIZO et al., 2015), the sheep from several Brazilian states (FÁVERO et al., 2002), and among the goats from Rio Grande do Sul State (SCHIMIDT et al., 2002). Nonetheless, an analysis of the serogroups from the northeastern semiarid regions show that the most frequent serotype was the incidence of Autumnalis infection (ALVES et al., 2012; ARAÚJO NETO et al., 2010; HIGINO et al., 2010; HIGINO et al., 2013). This raises the risk of possible human infection, since the incidence of leptospirosis infection often occurs occupationally (GENOVEZ, 2009), with the incidence of Icterohaemorrhagiae infection being highly pathogenic to humans (ADLER; DE LA PEÑA MOCTEZUMA, 2010).

The role of natural reservoirs warrants particular emphasis in the epidemiology of this disease. For instance, synanthropic rodents, such as rats (Rattus norvegicus), are considered maintenance hosts of the Icterohaemorrhagiae and Copenhageni serotypes (SPICKLER; LEEDOM LARSON, 2013), whereas wild animals, such as raccoons and opossums, act as reservoirs for the Grippotyphosa serotype (SALABERRY et al., 2011). Additionally, wild rodents are also considered hosts of the Autumnalis serotype (FAINE et al., 1999). The
Brazilian guinea pig (Cavia aperea), which is common in the semiarid regions (ALVES et al., 1996), acts as reservoirs of the Icterohaemorrhagiae serotype (CUBAS et al., 2007). It is thus possible that there is a relationship between the serotypes sampled in this study and the habitation of these hosts as potentially infectious agents. In intensive management systems, synanthropic rodents are sources of infection to the animals; the majority of the respondents $(7 / 12)$ reported rodent infestation on the properties.

Measures directed toward the control of synanthropic rodents are required in order to prevent the transmission of infection to small ruminants and to humans on the properties. Other wild reservoirs can be managed with legal barriers for the protection of the species, but further studies are required to elucidate the role of these animals in the epidemiology of this disease.

A potential practice that could complement the control of the disease would be to inoculate herds with bacterins containing the regional serotypes. Currently, however, this approach is unfeasible due to the lack of commercial availability for such vaccines. According to Higino and Azevedo (2014), information on the feasibility of small ruminant immunization is still limited, as the majority of the commercially available vaccines are intended for cattle, pigs, and dogs. However, rodent control and systematic immunization with inactivated vaccines containing the regional serotypes have shown efficacy in the control of leptospirosis in goats and sheep (FAINE et al., 1999).

Intensive management systems are considered risk factor for seropositivity due to the incidence of Leptospira spp. in goats. Additionally, extensive and semi-intensive management systems are also predominant in semiarid regions (COSTA et al., 2008). In animals that were bred semiintensively/extensively, a seropositivity of $4.8 \%$ was reported, while goats bred intensively showed a seropositivity of $24 \%$. As these rearing sites are 
characterized by a greater density of animals, there is a greater possibility of exposing susceptible animal populations to the sources of infection. This highlights the role of animal agglomerations in the dissemination of diseases (THRUSFIELD, 2007). Better hygiene conditions, such as more frequent cleaning of the facilities, could reduce the exposure time to the infectious agent, and thus minimize the risk of disease transmission.

A risk factor that has been associated with infection in goats is the practice of consort rearing with horses, as cohabitation between the two species may favor the transmission of the disease. Fávero et al. (2002) sampled higher rates of Icterohaemorrhagiae and Grippotyphosa serotypes from horses from various Brazilian states. Moreover, the prevalence of these serotypes in the goat species highlights the risk of infection in consort rearing with horses, as the horse species can act as a source of potential infection to susceptible animals in the rearing environment. In a study conducted by Hashimoto et al. (2010), the prevalence of different serogroups was evaluated in several species of animals exposed to the same sources of infection in the same region. Nonetheless, a more in-depth study is required to clarify the role of horses in the transmission of the disease to goats.

The accumulated rainfall in the studied municipalities was within the historical average for the region, which was below $800 \mathrm{~mm}$ per year (MOURA et al., 2007); however, the correlation between rainfall and seropositivity is questionable because of the discrepancies within the literature. For instance, the Tabira municipality, in the Pernambuco State, had the highest frequency of seroreactive sheep (14.75\%) and an accumulated rainfall of $584.6 \mathrm{~mm}$ (APAC, 2015). This observation was consistent with the conclusions of Alves et al. (1996), who stated that accumulated rainfall above $550 \mathrm{~mm}$ was sufficient to maintain and disseminate the disease in the northeastern semiarid region. Conversely, it was reported that the Casa Nova municipality, in Bahia State, had the highest rate of seropositive goats $(24.00 \%)$, despite an accumulated rainfall of only $310.8 \mathrm{~mm}$ (INMET, 2015). Nevertheless, it is suspected that the proximity of this municipality's location to the Hydrographic Basin of the San Francisco River may contribute to the persistence of microbial communities within the area. Geographically, the Sobradinho Lake also borders the southern part of this municipality, and has intermittent rivers along its interior (CPRM, 2005). Cortizo et al. (2015) reported that the open availability of water sources within the properties was also a risk factor for infection in the Espírito Santo State. This demonstrates the influence of environmental factors in the epidemiology of the disease.

The frequency of sheep seropositive to B. ovis in this study was consistent with results of the studies conducted in the northeastern regions. In Paraiba, Clementino et al. (2007) and Santos et al. (2013) reported seropositive rates of $5.67 \%$ and $5.20 \%$, respectively. Pinheiro Junior et al. (2009) reported a seropositive rate of $3.1 \%$ for their sample of animals from the Alagoas State, whereas Souza et al. (2012) reported that $0.72 \%$ of the animals sampled in the Bahia State were seropositive. Azevedo et al. (2004b) reported a seropositive rate of $11.3 \%$ in Rio Grande do Norte State, and Coleto et al. (2003) reported a rate of $16.25 \%$ in the Pernambuco State. These results reveal the dissemination pattern of the disease among sheep in the region, and stress the need for improved control practices.

The control of transit and agglomeration-like animal fairs is important because the infection may spread between herds, which may have been previously disease-free, through the acquisition of infected animals. Clementino et al. (2007) highlighted that the practice of selling animals without any health controls can become a route for the dissemination of $B$. ovis throughout the herds of the region. Santos et al. (2013) observed that $50 \%$ of the seropositive animals in the study participated in animal fairs and/or exhibitions, while those that did not participate in such events accounted for $19.3 \%$. 
These authors identified that the acquisition of such animals in these events posed as a risk factor for the transmission of the disease.

In this study, sheep bred intensively were 11.5 times more likely to be seropositive; therefore, this variable was identified as a risk factor for infection. Additionally, Clementino et al. (2007) observed that sheep bred within extensive systems in the semiarid regions of the Paraiba State were likelier to be seropositive, which differs from the observations reported in other studies regarding the influence of rearing type. Nonetheless, the intensive management system is characteristic of animal traders, who acquire, through purchase or from other forms of trade, small ruminants from properties in other regions, and confine them in small facilities until the time of sale. This process may last from a couple of days to weeks. It should be noted that the confinement conditions may favor the transmission and spread of diseases if there are no proper sanitary control measures in place. Magalhães Neto and Gil-Turnes (1996) reported that sheep maintained in a farm regime showed higher seropositivity for infection. This can be related to the management factors, such as the higher animal densities within the more confined spaces. Improvements to the sanitary practices of the rearing environments are thus recommended to reduce the exposure time of susceptible animals to presence of infectious agent, and to minimize the risk of infection.

\section{Conclusions}

The results suggest that the incidence of Leptospira spp. infection is spread in small ruminants, whereas infection by $B$. ovis occurs in sheep sold at animal fairs. Improvements in the hygiene and sanitary conditions of properties are recommended, mainly in those that practice an intensive management system. Additionally, the control of synanthropic rodents, with particular attention to cohabitating species in rearing environments, is warranted for reducing the risk of disease transmission to susceptible animal populations.

\section{Acknowledgements}

To the Pernambuco State Farming \& Livestock Defense and Inspection Agency (ADAGRO) for granting the data on animal flow and to the National Council for Scientific \& Technological Development (CNPq) for granting the scholarship and financial support necessary to develop the project.

\section{References}

ADLER, B.; DE LA PEÑA MOCTEZUMA, A. Leptospira and leptospirosis. Veterinary Microbiology, Amsterdam, v. 140, n. 3, p. 287-296, 2010.

AGÊNCIA PERNAMBUCANA DE ÁGUAS E CLIMA - APAC. Acumulado mensal de precipitação. Recife: Governo do Estado de Pernambuco, 2015. Available at: $<$ http://www.apac.pe.gov.br/meteorologia/ $>$. Accessed at: Dec 10, 2015.

AGUIAR, D. M.; CAVALCANTE, G. T.; VASCONCELLOS, S. A.; SOUZA, G. O.; LABRUNA, M. B.; CAMARGO, L. M. A.; GENNARI, S.M. Anticorpos anti-Leptospira spp. em ovinos do Município de Monte Negro, Estado de Rondônia. Arquivos do Instituto Biológico, São Paulo, v. 77, n. 3, p. 529-532, 2010.

ALVES, C. J.; VASCONCELLOS, S. A.; CAMARGO, C. R. A.; MORAIS, Z. M. Influência dos fatores ambientais sobre a proporção de caprinos soro-reatores para a leptospirose em cinco centros de criação do Estado da Paraíba, Brasil. Arquivos do Instituto Biológico, São Paulo, v. 63, n. 2, p. 8-11, 1996.

ALVES, C. J.; ALCINDO, J. F.; FARIAS, A. E. M.; HIGINO, S. S. S.; SANTOS, F. A.; AZEVEDO, S. S.; COSTA, D. F.; SANTOS, C. S. A. B. Caracterização epidemiológica e fatores de risco associados à leptospirose em ovinos deslanados do semiárido brasileiro. Pesquisa Veterinária Brasileira, Seropédica, v. 32, n. 6, p. 523528, 2012.

ARAÚJO NETO, J. O.; ALVES, C. J.; AZEVEDO, S. S.; SILVA, M. L. C. R.; BATISTA, C. S. A. Soroprevalência da leptospirose em caprinos da microrregião do Seridó Oriental, Estado do Rio Grande do Norte, Brasil, e pesquisa de fatores de risco. Veterinary Research and Animal Science, São Paulo, v. 47, n. 2, p. 150-155, 2010. 
AZEVEDO, S. S.; ALVES, C. J.; ANDRADE, J. S. L.; BATISTA, C. S. A.; CLEMENTINO, I. J.; SANTOS, F. A. Ocorrência de aglutininas anti-Leptospira em ovinos do Estado do Rio Grande do Norte, Brasil. Revista Brasileira de Ciência Veterinária, Niterói, v. 11, n. 3, p. 167-170, 2004a.

AZEVEDO, S. S.; ALVES, C. J.; ALVES, F. A. L.; CLEMENTINO, I. J.; BATISTA, C. S. A.; AZEVEDO, A. S. Ocorrência de anticorpos anti-Brucella ovis em ovinos procedentes de quatro municípios do Estado do Rio Grande do Norte, Brasil. Revista Agropeuária. Técnica, Areia, PB, v. 25, n. 2, p. 45-50, 2004b.

CLEMENTINO, I. J.; ALVES, C. J.; AZEVEDO, S. S.; PAULIN L. M.; MEDEIROS, K. A. Inquérito soroepidemiológico e fatores de risco associados à infecção por Brucella ovis em carneiros deslanados do semi-árido da Paraíba. Pesquisa Veterinária Brasileira, Seropédica, v. 27, n. 4, p. 137-143, 2007.

COLETO, Z. F.; PINHEIRO JÚNIOR, J. W.; MOTA, R. A.; GUERRA, M. M. P.; SIMPLÍCIO, K. M. M. G.; CÂMARA, D. R.; SOARES R. P. T.; PORTO, W. J. N.; CINTRA JÚNIOR, J.; FAUSTINO, M. A. G.; SOUZA, A. F.; BERTO, R. S. Ocorrência de infecção por Brucella ovis em ovinos do Estado de Pernambuco e sua participação em distúrbios reprodutivos nesta espécie. Revista Brasileira de Reprodução Animal, Belo Horizonte, v. 27, n. 3, p. 551-553, 2003.

CORTIZO, P.; RODRIGUES, P. R. do; FARIA, B. P.; DEMINICIS, B. B.; LOUREIRO, A. P.; MARTINS, G.; LILEMBAUM, W. Risk factors to incidental leptospirosis and its role on the reproduction of ewes and goats of Espírito Santo State, Brazil. Tropical Animal Health Production, Edinburgh, v. 47, n. 1, p. 231-235, 2015.

COSTA, D. F.; SILVA, A. F.; FARIAS, A. E. M.; BRASIL, A. W. L.; SANTOS, F. A.; GUILHERME, R. F.; AZEVEDO, S. S.; ALVES, C. J. Serological study of the Leptospira spp. infection in sheep and goats slaughtered in the State of Paraíba, semiarid of Northeastern Brazil. Semina: Ciências Agrárias, Londrina, v. 37, n. 2, p. 819828, 2016.

COSTA, R. G.; PIMENTA FILHO, E. C.; HOLANDA JÚNIOR, E. V.; SANTOS, N. M. Caracterização do sistema de produção caprino e ovino na região semiárida do Estado da Paraíba, Brasil. Archivos de Zootecnia, Córdoba, v. 57, n. 218, p. 195-205, 2008.

CUBAS, Z. S.; SILVA, J. C. R.; CATÃO-DIAS, J. L. Tratado de animais selvagens: medicina veterinária. São Paulo: Roca, 2007. 1376 p.
ELLIS, W. A. Animal leptospirosis. Current Topics in Microbiology Immunology, Berlin, v. 387, n. 1, p. 99137, 2015.

FAINE, S.; ADLER, B.; BOLIN, C.; PEROLAT, P. Leptospira and leptospirosis. 2. ed. Melbourne: MediSci, 1999. $272 \mathrm{p}$.

FÁVERO, A. C. M.; PINHEIRO, S. R.; VASCONCELLOS, S. A.; MORAIS, Z. M.; FERREIRA, F.; FERREIRA NETO, J. S. Sorovares de leptospiras predominantes em exames sorológicos de bubalinos, ovinos, caprinos, equinos, suínos e cães de diversos Estados brasileiros. Ciência Rural, Santa Maria, v. 32, n. 4, p. 613-619, 2002.

GENOVEZ, M. E. Leptospirose: uma doença de ocorrência além da época das chuvas! Arquivos do Instituto Biológico, São Paulo, v. 71, n. 1, p. 1-3, 2009.

HASHIMOTO, V. Y.; GARCIA, J. L.; SPOHR, K. A. H.; SILVA, F. G. da; ALVES, L. A.; FREITAS, J. C. de. Prevalência de anticorpos contra Leptospira spp. Em bovinos, caninos, equinos, ovinos e suínos do município de Jaguapitã, Estado do Paraná, Brasil. Arquivos do Instituto Biológico, São Paulo, v. 77, n. 3, p. 521-524, 2010.

HERRMANN, G. P.; LAGE, A. P.; MOREIRA, E. C. Soroprevalência de aglutininas anti-Leptospira spp. em ovinos nas Mesorregiões Sudeste e Sudoeste do Estado Rio Grande do Sul, Brasil. Ciência Rural, Santa Maria, v. 34, n. 2, p. 443-448, 2004.

HIGINO, S. S. S.; AZEVEDO, S. S.; ALVES, C. J.; FIGUEIREDO, S. M.; SILVA, M. L. C. R.; BATISTA, C. S. A. Frequência de leptospirose em ovinos abatidos no Município de Patos, Paraíba. Arquivos do Instituto Biológico, São Paulo, v. 77, n. 3, p. 525-527, 2010.

HIGINO, S. S. S.; SANTOS, F. A.; COSTA, D. F.; SANTOS, C. S. A. B.; SILVA, M. L. C. R.; ALVES, C. J.; AZEVEDO, S. S. Flock-level risk factors associated with leptospirosis in dairy goats in a semiarid region of Northeastern Brazil. Preventive Veterinary Medicine, London, v. 109, n. 1-2, p. 158-161, 2013.

HIGINO, S. S. S.; AZEVEDO, S. S. Leptospirose em pequenos ruminantes: situação epidemiológica atual no Brasil. Arquivos do Instituto Biológico, São Paulo, v. 81, n. 1, p. 86-94, 2014.

HOSMER, D. W.; LEMESHOW, S. Applied logistic regression. New York: John Wiley and Sons, 2000. 375 p. 
INSTITUTO NACIONAL DE METEOROLOGIA INMET. Banco de dados meteorológicos para ensino e pesquisa. Brasília: Governo Federal, 2015. Available at: $<$ http://www.inmet.gov.br/portal/index.php?r= bdmep/ bdmep>. Accessed at: Dec 10, 2015.

LILENBAUM, W.; SOUZA, G. N.; RISTOW, P.; MOREIRA, M. C.; FRÁGUAS, S.; CARDOSO, V. S.; OELEMANN, W. M. R. A. Serological study on Brucella abortus, caprine arthritis-encephalitis virus and Leptospira in dairy goats in Rio de Janeiro, Brazil. The Veterinary Journal, Amsterdam, v. 173, n. 2, p. 408-412, 2007.

MAGALHÃES NETO, A.; GIL-TURNES, C. Brucelose ovina no Rio Grande do Sul. Pesquisa Veterinária Brasileira, Seropédica, v. 16, n. 2-3, p. 75-79, 1996.

MARTINS, G.; PENNA, B.; HAMOND, C.; LEITE, R. C.; SILVA, A.; FERREIRA, A.; BRANDÃO, F.; OLIVEIRA, F.; LILENBAUM, W. Leptospirosis as the most frequent infectious disease impairing productivity in small ruminants in Rio de Janeiro, Brazil. Tropical Animal Health and Production, Edinburgh, v. 44, n. 4, p. 773-777, 2012.

MOURA, M. S. B.; GALVINCIO, J. D.; BRITO, L. T. L.; SOUZA, L. S. B; SÁ, I. I. S.; DA SILVA, T. G. F. Clima e água de chuva no semiárido. In: BRITO, L. T. de L.; MOURA, M. S. B. de; GAMA, G. F. B. (Ed.). Potencialidades da água de chuva no Semi-Árido brasileiro. Petrolina: Embrapa Semi-Árido, cap. 2, 2007. p. 37-59. Available at: $<$ http://www.alice.cnptia.embrapa. br/handle/doc/159649>. Accessed at: Dec 10, 2015.

NOGUEIRA FILHO, A.; FIGUEIREDO JÚNIOR, C. A.; YAMAMOTO, A. Mercado de carne, leite e pele de caprinos e ovinos no Nordeste. Fortaleza: Banco do Nordeste do Brasil, 2010. 128 p.

PINHEIRO JUNIOR, J. W.; OLIVEIRA, A. A. F.; MOTA, R. A.; AGOTTANI, J. V.; JESUS, E. M.; ASSIS S. T.; OLIVEIRA, C. Z. Ocorrência de ovinos sororeatores para Brucella ovis no Estado de Alagoas, Brasil. Veterinária e Zootecnia, Botucatu, v. 16, n. 3, p. 500-508, 2009.

RIZZO, H.; GREGORY, L.; BERALDI, F.; CASTRO, V.; DE MORAIS, Z. M.; VASCONCELLOS, S. A. Soropositividade para leptospirose e desempenho reprodutivo de ovinos de criatórios localizados no Estado de São Paulo, Brasil. Revista Brasileira de Medicina Veterinária, Rio de Janeiro, v. 36, n. 3, p. 244-250, 2014.

SALABERRY, R. S. S.; CASTRO, V.; NASSAR, A. F. C.; CASTRO, J. R.; GUIMARÃES, E. C.; LIMARIBEIRO, A. M. C. Seroprevalence and risk factors of antibodies against leptospira spp. in ovines from
Uberlândia municipality, Minas Gerais state, Brazil. Brazilian Journal of Microbiology, São Paulo, v. 42, n. 4, p. 1427-1433, 2011.

SANTOS, F. A.; HIGINO, S. S. S.; AZEVEDO, S. S.; COSTA, D. F.; FARIAS, A. E. M.; ALVES, F. A. L.; PAULIN, L. M.; ALVES, C. J. Caracterização epidemiológica e fatores de risco associados à infecção por Brucella ovis em ovinos deslanados do semiárido paraibano. Pesquisa Veterinária Brasileira, Seropédica, v. 33, n. 4, p. 459-463, 2013.

SANTOS, J. P.; LIMA-RIBEIRO, A.; OLIVEIRA, P.; SANTOS, M.; FERREIRA, A.; MEDEIROS, A.; TAVARES, T. Seroprevalence and risk factors for Leptospirosis in goats in Uberlândia, Minas Gerais, Brazil. Tropical Animal Health and Production, Edinburgh, v. 44, n. 1, p. 101-106, 2012.

SCHIMIDT, V.; AROSI, A; SANTOS, A. R. Levantamento sorológico da leptospirose em caprinos leiteiros no Rio Grande do Sul, Brasil. Ciência Rural, Santa Maria, v. 32, n. 4, p. 609-612, 2002.

SERVIÇO GEOLÓGICO DO BRASIL - CPRM. Projeto cadastro de fontes de abastecimento por água subterrânea - Bahia: diagnóstico do Município de Casa Nova. Brasília: Governo Federal. 2005. Available at: < http:// www.cprm.gov.br/rehi/atlas/bahia/relatorios/CANO040. pdf > . Accessed at: Dec 10, 2015.

SILVA, J. B. A.; FEIJÓ, F. M. C.; TEIXEIRA, M. F. S.; SILVA, J. S. Prevalência de brucelose ovina causada por Brucella ovis em rebanhos do estado do Rio Grande do Norte, Brasil. Ciência Animal, Fortaleza, v. 13, n. 1, p. 51-54, 2003.

SILVA, R. C.; COSTA, V. M.; SHIMABUKURO, F. H.; RICHINI-PEREIRA, V. B.; MENOZZI，B. D.; LANGONI, H. Frequency of Leptospira spp. in sheep from Brazilian slaughterhouses and its association with epidemiological variables. Pesquisa Veterinária Brasileira, Seropédica, v. 32, n. 3, p. 194-198, 2012.

SOUZA, T. S.; COSTA, J. N.; MARTINEZ, P. M.; LIMA, C. C. V.; ARAÚJO, B. R.; COSTA NETO, A. O.; ANUNCIAÇÃO, A. V. M.; ALMEIDA, M. G. A. R.; PINHEIRO, R. R. Inquérito soro-epidemiológico de Brucella ovis em rebanhos ovinos no semiárido baiano. Arquivos do Instituto Biológico, São Paulo, v. 79, n. 2, p. 277-281, 2012.

SPICKLER, A. R.; LEEDOM LARSON, K. R. Leptospirosis. The center for food security \& public health. Ames: Iowa State University. 2013. Available at: $<$ http://www.cfsph.iastate.edu/DiseaseInfo/factsheets. php $>$. Accessed at: Dec 10, 2015. 
THRUSFIELD, M. Veterinary epidemiology. 3. ed. Oxford: Blackwell Science, 2007. 624 p.

TOPAZIO, J.; TONIN, A. A.; MACHADO, G.; NOLL, J. C. G.; RIBEIRO, A.; MOURA, A. B.; CARMO, G. M.; GROSSKOPF, H. M.; MARTINS, J. L. R.; BADKE, M. R. T.; STEFANI, L. M.; LOPES, L. S.; SILVA, A. S. Antibodies to Leptospira interrogans in goats and risk factors of the disease in Santa Catarina (West side), Brazil. Research in Veterinary Science, London, v. 99, n. 1, p. 53-57, 2015.
WORLD ORGANIZATION FOR ANIMAL HEALTH OIE. Leptospirosis. Manual of standards for diagnostic tests and vaccines for terrestrial animals. Paris: World Organization for Animal Health, 2014. Available at: $<$ http://www.oie.int/fileadmin/Home/eng/Health_ standards/tahm/2.01.09_LEPTO.pdf $>$. Accessed at: Oct 10, 2015.

Ovine epididymitis (Brucella ovis). Manual of standards for diagnostic tests and vaccines for terrestrial animals. Paris: World Organization for Animal Health. 2015. Available at: <http://www.oie.int/fileadmin/Home/ eng/Health_standards/tahm/2.07.09_OVINE_EPID. pdf $>$. Accessed at: Sept. 10, 2015.

ZAR, J. H. Biostatistical analysis. $4^{\text {th }}$ ed. Upper Saddle River: Prentice Hall, 1999. 663 p. 
